Põe em relêvo a A. a atitude omissa dos tribunais franceses, que "nunca se julgaram com o direito de apreciar a constitucionalidade das leis", embora alguns juristas contemporâneos daquele país entendam que, se os tribunais não exercem o referido contrôle, é em conseqüência "d'une regrettable timidité".

O trabalho em aprêço, redigido com seguro conhecimento do assunto, reflete a realidade jurídica francesa da atualidade, com referência a êste tão relevante quão debatido problema do contrôle da constitucionalidade das leis, ao qual se prende o do gráu de supremacia da Constituição sôbre as leis ordinárias, diversamente encarados, um e outro, na Europa e na América.

Vê-se, através da evolução do direito constitucional francês e certamente mais do que através de sua evolução - mercê do inequívoco pendor que nêle se verifica, nesse sentido, que o duplo princípio solidário, acima enunciado, tende a derrocar o cânon da soberania do parlamento, sem prejuízo da manutenção dos elementos essenciais do sistema parlamentar de govêrno, o qual não implica necessàriamente a prevalência daquele postulado, filiado, ao pé da letra, ao item da "Declaração dos Direitos do Homem e do Cidadão" segundo o qual "la loi est l'expression de la volonté générale".

Somos de parecer, em vista do exposto, que o Congresso acotha o trabalho em aprêço como uma lúcida contribuição, sobremodo nútil e proveitosa, no âmbito do direito constitucional comparado, neste após-guerra, recomendando-o à atenção dos estudiosos da matéria.

Sala das Sessões, 17 de agôsto de 1950.

\section{DIREITO ADMINISTRATIVO E DIREITO PRIVADO}

\section{Ruy Cirne Lima}

Professor Catedrático de Direito Administrativo e Ciência da Administração na Faculdade de Direito da Universidade do Rio Grande do Sul.

\section{DIREITO ADMINISTRATIVO E DIREITO PRIVADO}

Aus sich selbst kann man nichts verstehen. Es ist immer nötig, die Gegenstände der Betrachtung mit anderem $\mathrm{zu}$ vergleichen und alsdann zuzusehen wie sie einheitlich erfasst und festgehalsten werden können.

Stamler, Theorie der Rechtswissenschaft, Halle, 1911 , p. 779

Estamos longe da época, em que, para explicar a manifestac̃o no Direito Administrativo de categorias jurídicas, já conhecidas no Direito Privado, se postulava abolir a distinção tradicional entre essas duas secções do direito positivo (e. g. Posada, Tratado de Derecho Administrativo, Madrid, 1897, t. I, n. ${ }^{\circ} 11$, p. 72),

Mas, ao revés, a intransigência em manter rigorosamente a vetha distinção romana vem gerando, na literatura do Direito Administrativo, a multiplicação de "novidades", que só o esquecimento completo dos dogmas privatísticos autorizaria fôssem consideradas tais.

Parece oportuno, pois, empreender-se o estudo dos institutos e figuras jurídicas do Direito Administrativo, em comparação com as espécies paralelas do Direito Privado, criando-se, destarte, um como Direito Comparado "ad intra", nêsse setor importantíssimo da investigação jurídica.

Os dois ensaios que seguem, são uma contribuição a êsse "desideratum".

25 - R. D. - 2. Vol. 
$\S 1$

\section{ATO ADMINISTRATIVO E ATO JURÍDICO PRIVADO}

1. A presunção de legitimidade, de que o ato administrativo: se reveste, faz se afirme que a administração pública goza do privilégio de poder enganar-se (1). Entretanto, se quisermos determinar o traço distintivo, pelo qual o ato administrativo se sepaar do ato jurídico privado, havemos de buscá-lo nessa como onisciência jurídica da administração, que vai pressuposta na adequação perfeita da vontade declarada a todos os efeitos, de que é jurìdicamente capaz, adequação essencial à natureza mesma do ato. administrativo.

Ao particular, admite-se que ignore êle alguns, ao menos, dos. efeitos, de que é suscetível o ato jurídico a ser praticado (2). Ao poder público, não; supõe-se, antes, que êle os conheça, a todos, com minuciosa exatidão, até as consequências derradeiras.

Certo, não raro, já a norma administrativa tende a aliviar a. ônus dessa cognição lógico-jurídica, pleníssima pela extensão, que. se reclama à administração em face do ato administrativo. Oto Mayer aflora o conceito, ao observar que as normas administrativas trazem como conteúdo, em fração maior ou menor, a substância mesma do ato que regulam $\left({ }^{3}\right)$. Mas isso não acontece em todos os casos. Antes acontece, às vezes, que o ato completa a norma, elevando-se, êle próprio, à condição de fonte jurídica derivada, como se verifica tão freqüentemente nas manifestações da assim chamada discreção adminiștrativa $\left({ }^{4}\right)$.

Não obstante, diz-se do ato administrativo que os efeitos dêle encontram a sua fonte no ato mesmo, isto é, na vontade da administração, e se operam, portanto, na medida em que são queridos pelo autor do negócio jurídico ( ${ }^{5}$ ).

Tais peculiaridades, próprias do ato administrativo. são meramente o reflexo da pecularidade, mais flagrante ainda, própria do sistema jurídico, em que o ato administrativo se insere.

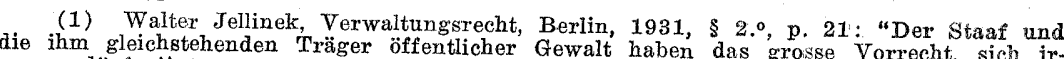
ren zu duirfen".

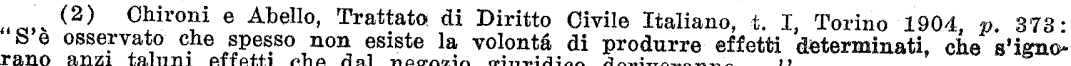

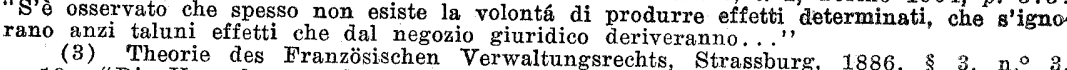

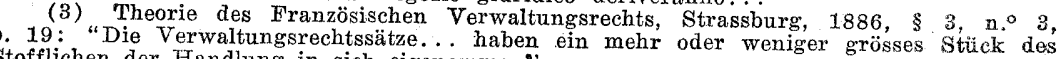
(4) Cf. Ferrucio Pergolesi, Saggi su le Fonti Normative, Milano, 1943, 今 29, p. 76 :

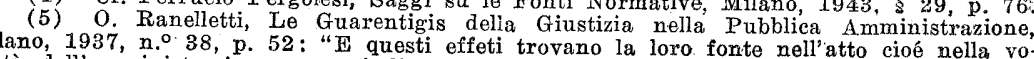
Milano, 1937, no. 38, p. 52: "E questi effeti trovano la loro fonte nell'atto cióe nella vo-
lonta dell'amministrazione; e quindi hanno luogo in quanto sono voluti dell'autore del
negozio".
2. Na sistemática do Direito Administrativo, o conteúdo do ato administrativo, ou a norma jurídica o determina coativamente, premoldando a vontade da administração; ou esta o há de querer em todos os seus efeitos e conseqüências. Dimana a atlernativa de uma razão simplíssima, a de que não há no Direito Administrativo normas dispositivas ou supletivas.

As mesmas normas jurídicas, das quais a administração recebe poder discricionário ou, seja, as pertinentes à assim chamada discreção administrativa, são essencialmente normas cogentes. James Goldschmidt advertiu agudamente que a discreção do juiz, no processo, não resulta de normas dispositivas, mas cogentes $\left({ }^{6}\right)$. A observação aplica-se à discreção administrativa, que não é uma faculdade, senão um dever da administração; e porque é um dever, irrenunciável e ilimitável por arbítrio desta, - dever prescrito, de resto, no interêsse da finalidade, a que tôda a atividade administrativa se vincula $\left({ }^{7}\right)$,e não no interêsse subjetivo da administração "qua talis".

À inexistência de normas administrativas, de caráter dispositivo ou supletivo, deve-se, portanto, não sòmente o princípio de que todos os efeitos do ato administrativo hão de ser queridos pela administração, senão também a postulação, aí implícita, de uma como plenitude lógico-jurídica do ato administrativo, sòmente comparável à que se afirma, alhures, como atributo da ordem jurídica supra-positiva.

$\mathrm{Na}$ verdade, quando não executa norma jurídica, de conteúdo preciso, a administração, ao praticar, em tais têrmos, um ato administrativo, de alguma forma, revela direito. Maior ou menor razão assistia, realmente, a Oto Mayer, ao dizer que, na ausência de norma jurídica imediatamente aplicável, age a administração paralelamente à lei positiva, como poder de igual origem, tendo na divisão constitucional dos podêres a sua legitimação jurídica ( 8 ).

$\mathrm{E}$ atentos êsses pressupostos, não admira, pois, se pretenda atribuir ao ato administrativo a mesma plenitude lógico-jurídica que, cabível à ordem jurídica supra-positiva, já se pretendeu, sem embargo, atribuir à lej positiva, ainda quando se devesse, no concer.

(6) Teoria General del Proceso, Barcelona, 1936, n.० 31, p. 72

(7) Nossa Preparação à Dogmática Jurídica. Pôrto Alegre, 1949, p. 57 ; nossa
trodução ao estudo do Direito Administrativo Brasileiro, Pôrto Alegre, 1942, \$ $2 .^{\circ}$, n. ${ }^{4}$ a 8 , p. 18 a 22. dann frei neben dem Gesetze als ebenbürtige Gewalt... Die Verfassungsmässige Machtvertheilung. allein ist ihr dafür die massgebende Rechtsordnang. A mesma idéia informa a. definicâa, "ein der Verwalt, Finzelfall bestimmt, was für ihn Rechtens sein soll". Of. Le Droit Administratif Allemand, t. I, Paris, 1903, \& 8, p. 120 
nente a esta, reconhecer que "a onisciência do legislador é uma ficção, de vez que é uma impossibilidade" $\left({ }^{9}\right)$.

3. Não significa, porém a apontada analogia entre a lei e o ato administrativo que êste não se possa qualificar como negócio jurídico. A lei mesma pode ser concebida como um negócio jurídico. Papiniano chamava-lhe já "communis reipublicae aponsio" $\left({ }^{10}\right)$; e os mesmos regalistas do século XVII não repudiam a concepção pactícia da lei. O nosso Domingos Antunes Portugal, a propósito, escreveu: "non praesumitur Principem habuisse voluntatem obligandi populum per legem, dum illam non acceptat, et sub conditione acceptationis legem tulisse intelligitur" (11).

A consequiência, entretanto, que se deve tirar da afinidade evidente entre o ato administrativo e a lei, é meramente a de que, no ato administrativo, alguma cousa existe, que existe também na lei, mas não se encontra no ato jurídico privado. Êsse "quid" específico, se quisermos ir diretamente ao fundo do problema, é a impessoabilidade, levada ao máximo, na determinação da vontade que, pela lei ou pelo ato administrativo, se exterioriza, a par do enunciado jurídico nêles contido.

Pode descobrir-se, decerto, maior ou menor impessoalidade na determinação da vontade, quando da prática de atos jurídicos privados; assim nos atos jurídicos do pai, ou da mãe, enquanto administrador dos bens dos filhos (Cód. Civ., art. 386); nos dos tutores e curadores (Cód. Civ., art. 439); nos dos representantes das pessoas jurídicas (Cód. Civ., art. 29 I), etc. Mas essa impessoalidade, pela qual se reconhece meramente a comunhão, entre o Direito Privado e o Direito Público, quanto ao conceito de administração, se pode ser qualificada como tal "ad intra", face aos círculos de interêsses a que respeita, mostra-se "ad extra", antes como um reflexo da personificação, mais ou menos definida, dêsses mesmos círculos de inerêsses, perante a sociedade, havida como um todo, em que se inserem êles como partes.

A lei e o ato administrativo deparam-nos, ao revés, a impessoalidade na determinação da yontade, levada ao máximo. $O$ círculo de interêsses, a que a lei e o ato administrativo dão expressão, é coextensivo com a própria ordem jurídica positiva vigente ou, seja, com o ordenamento jurídico da sociedade, como um todo.

A limitação nacional do direito positivo faz dêsse círculo de interêsses o círculo máximo na sociedade politicamente organizada.

(9) Walter Jellinek, Gesetz, Gesetzanwendung und Zwecksmässgkeitserwägung, Tübingen, $1913, \& 8, p, 166 ;$
sie ist eine Unmöglichkeit',

(10) Dig., lib. I, tit. III, de legibus, fr. 1 ; cf. fr. 2 h. t.
(11) De Donationibus Jurium et Bonorum Regiae doronas, Lugduni, 1726,
Já Bártolo sinalava que a apelação interposta de decisão do regente de comunidade "superiorem non recognoscens", haveria de ter como juiz "ipse populus... qui ipsum officialem fecit" $\left.{ }^{12}\right)$.

4. A impessoalidade na determinação da vontade atinge, realmente, na lei e no ato administrativo, o máximo, de que é susceptível, comensurando-se, na sociedade politicamente organizada, não só à ordem jurídica positiva, senão também à finalidade mesma da sociedade como tal ou, seja, abstração feita da personificação estatal, à utilidade pública, dita, às vêzes, também, utilidade social.

De Gérando e Macarel exprimiram a mesma idéia, o primeiro, ao escrever, do Direito Administrativo, que "l'utilité publique est toujours engagée dans le matières qu'il embrasse" ( $\left.{ }^{13}\right)$; e o segundo, ao dizer, da administração, que "son but unique est l'utilité sociale" (14).

Ao mesmo propósito, alhures anotámos: "Que é utilidade pública? Tal como a concebemos é a expressão social do Bem Comưm, a definição dêste "sub specie societatis". O Bem Comum é mais do que a simples multiplicação aritmética, pelo número dos indivíduos na coletividade, do bem de cada qual. "Bonun commune. - adverte Santo Tomás, - et bonum singulare uius personae non differunt solum secundum multum et parvum, sed secundum formalem differentiam" (Summa Theologica, IIa. IIae, q. XXVII, art. 6). Êrro inexcusável seria, com efeito, atender-se em tal caso, sòmente aos indivíduos e às relações dêstes entre si, deixando-se em esquecimento que essas relações supõem já, de alguma forma, a existência da sociedade. Erro maior, porém, seria referir-se à sociedade mesma a noção de Bem Comum. A sociedade e os fins desta são meramente meios para que o homem realize o próprio fim (Santo Tomás, De Regimine Principum, lib. I, cap. $X I V)$. A unidade social é, apenas, a unidade da ordem, e não a dos organismos naturais (Santo Tomás, Commentaria in Decem Libros Ethicorum, lib. I, lect. I). Sujeito, por conseguinte, a que o Bem Comum se proponha sòmente pode ser o homem, - o indivíduo, na sociedade, enquanto componente dela ou, seja, enquanto parte do todo, interessado como tal na conservação dêste. $\tilde{A}$ sua vez, e ainda, como conseqüência, a distinção entre o Bem Individual e o Bem Comum sòmente pode estar em que o primeiro vai referido ao indivíduo sôbre si, ao passo que o último se lhe refere, enquanto parte do todo, cuja conservacão lhe é um bem, em si mesma: "alia est ratio boni communis et boni singularis, sicut

(12) Commentaria, t. VI, in Secundam Digesti Novi Partem, Venetiis, 1602, p. 194

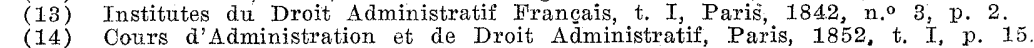


alia est ratio totius et partis" (Santo Tomás, Summa Theologica, IIa. IIae. q. XXVI, art. 6). Um filósofo, que fala como jurista, ensina-nos que o Bem, da Filosofia Moral, corresponde ao "frui" do Direito: é a satisfação de uma inclinação, um gôzo; enquanto o Util se equipara ao "uti" do jargão jurídico: é a utilização, o meio pelo qual se alcança o "fruit" (E. Baudin, Introduction Générale à la Philosophie, t. I, Paris, 1932, p. 18). A sociedade, se não é capaz de um gôzo (o que suporia sensibilidade), é, sem dúvida, capaz, de um "uti", quer dizer de utilizar (o que supõe, dúvenas, um ordenamento social das atividades individuais) os múltiplos recursos a seu alcance, riquezas morais e riquezas materiais, de sorte a assegurar a cada qual, como os meios de persecução do bem privado que the toca como indivíduo, as condições essenciais ao Bem Comum, que the interessa como membro da coletividade" (15).

Êsse, o conceito de utilidade pública, e êsse, pois, o fim a que, sem acepção subjetiva, impessoalmente, o legislador e a administraçõ̃ se adscrevem em sua atividade: "hoc est Reipublicae officium" $\left({ }^{16}\right)$.

Quanto ao legislador, a impessoalidade, ou the é imposta pelo dever de enunciação da regra jurídica, gerada na matriz do Direito Natural; ou lhe é exigida diretamente por aquela vinculação finalística, quando the cabe fixar a norma a ser editada "per modum determinationis", em uma como opcão ser editada "per modum à administração, a impessoalidade lhe é imposta pelo dever de execução da norma, de conteúdo preciso; ou imediatamente exigida pela mesma vinculação finalística que, de resto, levando aqui mais undo a sua influência caracteriza e define a mesma atividade administrativa como um tipo específico de relacionamento jurídico. A êsse respeito, escrevemos noutra oportunidade: "O caráter finalístico e teleológico da atividade administrativa não é, sem dúvida, o único a sinalar especificamente essa forma de atividade. Mas não há negar que constitui a nota principal dentre quantas compóem o conceito de administração. Na verdade, ao passo que o direito subjetivo vincula os fatos e os bens do mundo exterior imediatamente a um sujeito, a administração vincula-os a um fim. O sujeito do direito subjetivo, ao exercê-lo terá um fim em mira; mas o fim influirá sôbre o bem ou fato, objeto do direito, imediatamente, através do sujeito. Diversamente, a atividade ad ministrativa "qua talis" obedece a um fim, a que o agente é obri-

(15) Nossa Introdução cit. \& $1, \ldots \mathrm{n}^{\circ} 5, \dot{\mathrm{p} .}, 12$ e 13.

(16) Warnkoenig, Institutiones Juris Romani Privati, Bonnae, 1834, 833, p. 10.

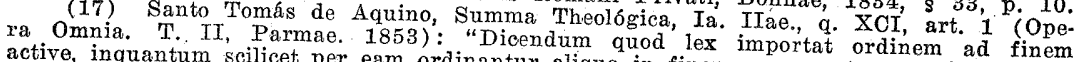
active, inquantum scilicet per eam ordinantur aliqua in finem; non autem passive, fidem
quod ipst,
extra ips lex ordinetur ad finem: nisi, per accidens, in, gubernante cujus finis est gado a adscrever-se, quaisquer que sejam as suas inclinações pessoais; e êsse fim domina e governa a atividade administrativa, a ponto de caracterizar-se, em vulgar, a boa administração pelà impessoalidade" (18).

5. A impessoalidade na determinação da vontade restringese, quanto à administração, ao ato administrativo, não se estendendo aos atos jurídicos privados, que a administração acaso pratique. Atos de Direito Privado, a administração os pratica no interêsse do Estado como pessoa jurídica ou no das pessoas administrativas menores, equiparadas àquêle como portadoras de poder público. A impessoalidade cede, então, o lugar à pessoalidade, quer dizer aos interêsses peculiares de uma pessoa jurídica determinada.

Traduz-se històricamente o mesmo discrime na concepção, velha e revelha, do Fisco, como personificação dos interêsses privados do Estado ou como um aspecto particular da personalidade jurídica estatal, no concernente a êsses interêsses (19).

6. A mesma impessoalidade explica-nos, de outra parte, por que o ato administrativo há de necessàriamente emanar do Estado ou de outra pessoa administrativa menor $\left({ }^{20}\right)$.

De feito, a impessoalidade, como a definimos, na determinação da vontade declarada pelo ato administrativo, sòmente a podem ter - Estado e as pessoas jurídicas de Direito Público, a êle equiparadas. Sòmente o Estado e as pessoas administrativas menores são capazes, em sua atividade administrativa, de comensurar-se, como potência, à utilidade pública, como ato; sòmente êles podem dizer-se "ad hoc" instituidos e organizados.

Ao demais, a mesma impessoalidade revela-nos por que o ato administrativo tem a seu favor a presunção de legitimidade, justificada pelo princípio, a que inicialmente aludimos, segundo o qual a administração pública goza do privilégio de poder enganar-se. A impessoalidade na determinação da vontade purifica o ato administrativo; fá-lo presumir isento dos defeitos que o caráter pessoal the poderia imprimir, oriundos da varibilidade dos interêsses, de que a pessoa é suscetível.

7. Como contraparte dessas conclusões, devemos reconhecer, ainda, que as normas jurídicas, que regem o ato administrativo, como as que regem a legislação ${ }^{21}$, hieràrquicamente se sobrepõem às

(18) Nossa Preparação cit., p. 57 e 58.

(19) Cf. Gerber. Grundziige des Deutschen Staatsrechts, Leipzig. 1880, \& 1 , mota 2, p. $2 ; .87$. nota $3, p .21$.
$(20)$ Of. Guido Zanobini, Corso di Diritto Administrativo, t. I, Milano, 1936, p. 277: " " "che la dichiarazione sia propria di un soggetto della pubblica amministra(21) Kormann-List, Einführung in die Praxis des Deutschen Verwaltungarechts Tübingen, 1930, p. 90 e 91 , falam de xum direito próprio da legislacão, "Gesetzgebun- 
normas jurídicas dispositivas ou supletivas do Direito Privado. Aquelas, pela impessoalidade dos atos que regem, têm algo de absoluto $\left({ }^{22}\right)$ estas, ao contrário, pela pessoalidade dos atos que lhes estão subme tidos, são necessàriamente contingentes. Quando Papiniano escreveu: "jus publicum privatorum pactis mutari non potest" $\left({ }^{23}\right)$, não pretendeu significar, sem dúvida, cousa diversa.

Vemos, destarte, reaparecer aqui, necessitado pelo desenvolvimento da disquisição teórica, o fato a que, como fato, já nos havíamos referido, da inexistência de normas dispositivas ou supletivas, na regulação jurídica do ato administrativo (24).

8. Resumindo, já agora, quanto ficou dito, podemos conceituar o ato administrativo como um ato jurídico, com enderêço exclusivo à utilidade pública, "quoad causam finalem", cujo sujeito há de ser necessàriamente o Estado, ou outra pessoa administrativa menor, e cuja disciplina jurídica consistirá em disposições cogentes específicas, ditas de Direito Administrativo, seja qual fồ a sua feição formal.

Persiste, nesse conceito, a noção de ato jurídico; varia tão-sòmente o critério de sua aplicação.

Nenhuma palavra melhor encerraria, pois, êste ensaio do que a de Ulpiano, sôbre a distinção entre o Direito Privado e o Direito Público: "hujus studii duae sunt positiones" $\left({ }^{25}\right)$; acrescida, porém, da glosa de Baldo: "id ist, dues species praedicabiles de suis sub.jectis" $(26)$.

\section{$\$ 2$}

\section{DOMÍNIO PÚBLICO E PROPRIEDADE PRIVADA}

1. Deve-se a construção contemporânea da doutrina do domínio público a Jhering e a Brinz: Jhering desbastou o terreno, Brinz: assentou os alicerces da construção nova.

Jhering negou que fossem "a propriedade e os direitos que dela nascem... a única forma possível de direitos sôbre as cousas" (1).

Brinz, à sua vez, afirmou a distinção entre o vínculo jurídico do patrimônio à pesșoa e o vínculo jurídico do patrimônio ao fim, a que é destinado: alí, a propriedade; aqui, o "Zweckvermögen”, o patrimônio-fim, a pessoa jurídica $\left({ }^{2}\right)$.

Como contraparte à sua posição negativa, face ao problema, propôs-lhe Jhering um símile por solução: meus cabelos pertencemme; se os corto, passam a ser propriedade minha $\left(^{3}\right)$. Enganou-se, entretanto, e duplamente: primeiro, quando teve como subentendido que todo vínculo jurídico devesse constituir direito em sentido subjetivo; segundo, quando supôs que a só pertinência física bastasse para dar ser a êsse direito $\left(^{4}\right)$.

Mérito foi de Brinz o ter afastado do problema, senão a noção de direito subjetivo, ao menos a idéia de sujeito de direito, naquela pressuposta. Substituíu-a, é certo, pela noção de patrimônio-fím ou, seja, de pessoa jurídica, também estranha à questão. Dentro, porém, na noção de pessoa jurídica, compreende-se a noção de administração, e esta, a nosso ver, é o dado essencial, do qual a solução procurada depende principalmente. A propósito da sociedade, substrato de uma das formas mais freqüentes de personalidade jurídica, Rodino disse excelentemente: "não pode haver sociedade sem administração", isto é, sem "aquela série de atos econômicos e jurídicos, pelos quais... (a sociedade) explica a função e consegue o fim, que lhe são objeto" $"(5)$.

No conteúdo da noção de administração, concebida como forma de atividade, encontramos, realmente, o ponto de partida para a solução ido problema.

2. Administração e direito subjetivo são dois tipos distintos de relacionamento jurídico. Alhures escrevemos: "A palavra admi-

n. 71 . p. L'Esprit du Droit Romain, trad. de O. de Meulenaere, t. IV, Paris, 1888, (2) Lehrbuch der Pandelten, Erlangen, 1886, t. III, \& 432, p. 457; "Inso-
lange nicht der Zweck anstatt des Subjektes als Gehörpunkt des Vermögens lange nicht der Zweek anstatt des Subjektes als Gehörpunkt des
kaant wird, ist Zweckvermögen in meinem Sinne nicht vorhanden".

(3) Ob. cit., t. IV, ñ. 71 , nota 534, p. 348.
(4) Nossa Preparaça à Dogmatica Juridica, Porto Alegre, 1949, p. 50.
(5) Società Civile, n. 413, Digesto Italiano, t. XXI, Torino, 1895-1902, p. 756. do Direito "Normas absolutas", chama-se às do direito cogente. Cf. Espinola, Sistem (23) Dig. lib. II, tit.
(24) V. supra, p. 10.
(25) Dig., lib. I, tit

(26) In Primam Digesti Veteris Partem, Venettis, 1616, lib. I, tit. I, de jus. 
mistração costuma empregar-se, em Direito Privado, por oposição a propriedade. Aos atos de administração, o Código de Napoleão opõe os atos de propriedade (art. 1988). Viciosa, embora, a expressão "actes de propriété" sublinha bem o contraste. Administração se diz, assim, a atividade do pai, ou da mãe, relativamente aos bens dos filhos; a dos tutores, relativamente ao patrimônio dos tutelados. Administração chama-se também à atividade dos dirigentes de associações, sociedades e fundações. Em todos êsses passos, vemos, realmente, separadas a propriedade, ou titularidade, e a administração. Qual o critério dessa separacão? $\mathrm{O}$ da finalidade do bem. Enquanto a propriedade, ou titularidade, opera a vinculação do bem ao sujeito de direito, a administração vincula o mesmo bem ao fim, a que deve servir. O fim, a que natural ou juridicamente, por destinação econômica ou prescrição legal, o bem deve servir, determina os limites da administração. Inepto o sujeito de direito para realizar êsse fim, separam-se a propriedade, ou titularidade, e a administração, para atribuir-se, esta, a pessoa capaz" $\left({ }^{6}\right)$.

3. Sem embargo, no Direito Privado, pela natureza mesma de suas manifestações, a tividade administrativa se nos apresenta dispersa e múltipla, irredutível a uma forma unitária. Diversamente, no Direito Público, a atividade administrativa, centralizada ou descentralizada, supõe, em qualquer caso, um núcleo central unitário, do qual ou para o qual procede, - um centro, enfim, que lhe atribui e mantém a unidade. Êsse centro é o Estado.

Em ambas as províncias jurídicas, o conceito de administração, entretanto, não varia essencialmente, embora, nó Direito Público a influência $\mathrm{e}$ as repercussões do conceito sejam incomensuràvelmente mais extensas do que no Direito Privado. Na verdade, pôsto a administração seja essencialmente uma relação, pela qual um fato ou um bem se vincula imediatamente a um fim, êsse mesmo fím necessàriamente há de determinar ,não sòmente o desenvolvimento da atividade como tal, senão, também, a disposição e o aparelhamento do agente "quoad actionem". Se o agente fôr, a exemplo do Estado, uma pessoa jurídica, a disposição dêle para a ação traduzir-se-á por uma forma determinada de oroanização. A atividade administrativa, realmente, é que determina a organizacão administrativa do Estado. À Ciência do Direito Administrativo, - digâmo-lo, de passagem, - e não à do Direito Constitucional, pertence, destarte, "à bon droit", o estudo da organização administrativa do Estado, ainda que fixada no direito positivo, por diplomas constitucionais.
Dentro na noção de organização "lato sensu", cabe, ainda, porém a aparelhamento necessário ao desenvolvimento da atividade administrativa: "organon", é sabido, significa precisamente instrumento. Nesse aparelhamento, a parte mais saliente é constituida pelos bens do domínio público. Diz-se dêsses bens que participam e no mais alto gráu, da atividade administrativa; e pode, com verdade, dizer-se que participam êles da administração, porque são parte instrumental, são órgãos ou pertenças materiais do agente, "inquantum ad actionem".

A mesma ontologia ensina nos que há unidade real, embora acidental, entre o operário e a ferramenta, enquanto à obra a realizar, - unidade, a que apropriadamente se chama unidade dinâmica $\left({ }^{7}\right)$. Unidade dinâmica existe, por igual, entre o agente e os bens instrumentais, relativamente à atividade administrativa a desempenhar $\left({ }^{8}\right)$.

4. A pertinência de um bem a uma pessoa, significando um senhorio sôbre o bem, análogo ao domínio, mas diverso dêste, porque limitado pelo fim, que o mesmo bem está destinado a servir, - essa relação achâmo-la já definida no mesmo Direito Romano, sob os traços do "jus sepulchri". Lê-se no Digesto de Justiniano, acêrca da significação das palavras: "Verbum illud "pertinere" latissime patet: nam est eis rebus petendis aptum est, quae domini nostri sont, et eis quas aliquo jure possideamus, quamvis non sint nostri dominii" $\left({ }^{9}\right)$. Ora, "pertinere" é o verbo que as fontes elegem para caracterizar a relação nascida do "jus sepuIchri”, inconfundível com o domínio " $\mathrm{Ei}$ ad quem pertineat (sepulchrum)"; "si nemo erit ad quem pertineat", diz-se no Edito do Pretor $\left({ }^{10}\right)$. Aí talvez, a origem do símile, proposto por Jhering, à guisa de solucão do problema do domínio público (meus cabelos pertencem-me) - nessa conceituação da pertinência de uma cousa a uma pessoa, como relação de senhorio, análoga ao domínio, mas distinta dêste.

Bens havidos como pertenças de cargos ou dignidades aparecem-nos, mais tarde, de resto, fora já da situação excecional do "jus sepulchri". Jorge de Cabedo anotou, em seu tempo: "Rex donavit cuidam nobili oppida quaedam, declarando quod illa ei donabat com omnibus sus pertinentiis, jurisdictione et dominio, et cum patronatibus Ecclesiarum ad Regem spectantibus in illis oppidis" (11). Antônio Perez, à sua vez, deixou-nos definida a compreensấo do que, na época, se entendia por pertenças em Direito Pú-

(7) Card. Mercier, Ontologia, Louvain-Paris, 1923, n..$^{\circ} 76$, p. 165

(7) Card. Mercier, Ontologia, Louvain

(9) Dig. lib. L, tit. XVI, de verborum significatione, ffr. 181.

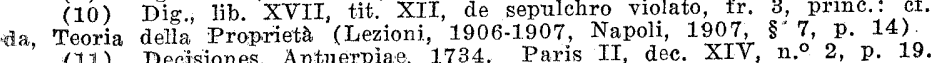


blico: "per concessionem jurium aut donationem castri cum suis pertinentiis, jurisdictionem non transferri... unde ea concessione tantum comprehenduntur proventus qui ex castro percipuntur" (12). Unidos, tais direitos ou proventos, à dignidade de conde, chama-se-lhes, noutros documentos e em melhor latim, "pertinentia comitatus" $(13)$.

5. Nessa relação de pertinência, ínsita na noção de adminis tração, funda-se tôda a construção jurídica do domínio público.

Não poderá haver, realmente, conceituação satisfatória do domínio público, que não faça lugar à possibilidade de propriedade privada sôbre os bens que o compõem, sem prejuízo, ou embaraço de sua destinação administrativa (14). Velho e revelho já no mesmo Direito Romano (1.6), êsse aspecto do problema do domínio público é agravado modernamente pela desenvoltura técnica, com que o Estado se move na gestão dos interêsses públicos, premido pela urgência, filha da imperiosa continuidade, essencial a execução dos serviços públicos. Daí a freqüência cada vez maior com que verifica a incorporação de bens particulares ao domínio público, sem que se extinga sôbre êles, anterior ou concomitantemente, o domínio privado dos proprietários, paralisado, apenas, em seu exercício.

Ora, sòmente um tipo de relação jurídica, diverso da figura do direito subjetivo (de que o domínio é seguramente a expressão mais vigorosa), poderá explicar a incorporacão ao domínio público de bens vinculados, pelo laço da propriedade privada, a um sujeito de

tit. $X, 12)$ Praelectiones in Duodecim Jibros Codicis Justiniani, ad lib. $X$, tit. $X$, tit. $\mathrm{X}, \mathrm{n}^{\circ} \mathrm{o}^{\mathrm{O}}$, Opera Varia, Venettis, 1738 , t. II, p. 177. varez Lopes, Barcelona, 1935, \& 18, p. 64. Outras fórmulas "...cum omnibus Ariman. nibus et quod pertinet ad comitatum,": ". . cum Arimannia et cum Sernitio quid per.

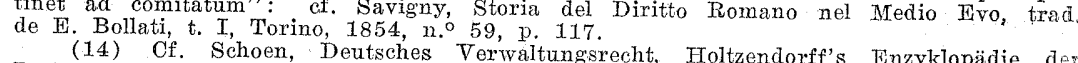
Rechtswissenschfat (herausgegeben von Josef Kohler), Leipzig-Berlin, 1914, to IV der 281; Walter Jellinek, Verwaltungsreeht, Berlin, 1931, \& 22, p. 507; Bounard, Pré Administratif, Paris, 1936 , Paris, 1935, p. 459; Waline, Mannel Elémentaire de Droi sileiro, Pôrto Alegre, 1939, § 7, p. 63; Tito Prates da Fonseca, Liḉes de Direito Ad ministrativo, Rio de Janeiro, 1943, p. 276; Zanobini, Corso di Diritto Amministrativo, II, no 678, p. 435; ete.

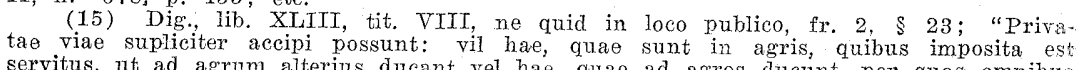
permeare liceat in quas exitur de via consulari. quae ad agros ducunt, per quas omnibus vel actus ad viliam ducens; has ergo quae post consularem excipiunt in vills vel in alias colonias ducentes, putem etiam ipsas publicas esse" (cf. Glicks, Commentario alle Pis, lib, XI. tit I de parte the pit meam ipsum meum privatum est, usus e jus publicus intelligitur"; Cod., lib. XI, tit. XIIII,

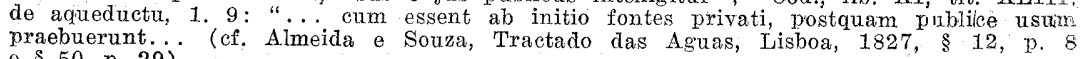
at direito, estranho por completo à atividade administrativa, de que aquêles bens participam. $\left({ }^{68}\right)$.

Êsse diverso tipo de relação jurídica, encontramo-lo, - fôrça é dizê-lo, mais uma vez, - na noção de administração.

6. O primado da destinação do bem, na construção jurídica do domínio público, revela-se, à evidência, pelas mesmas manifestações exteriores dessa destinação. $O$ uso público, sob a forma de uso comum, é, fora de dúvida, o mais decisivo têrmo de contraste entre o domínio público e a propriedade privada em seu exercício normal.

Não nos cabe certamente retomar a secular discussão acêrca da distinção entre as "res jure gentium communes" e as "res publicae"; cabe-nos, antes, repetir, a tal propósito, as expressões de Voet: "non hic occupatur disputatione prolixa, an res publicae distinguandae veniunt a rebus jure gentium communibus, an non psae res jure gentium communes vulgo dictae re ipsa sint publicae" (17).

$\mathrm{Na}$ verdade, se entendemos que o conceito de domínio público se separa do de propriedade, a controvérsia escassamente poderia interessar-nos, versando, como versa, exatamente sôbre a inapropriabilidade das "res communes" e a propriedade pública das "res publicae". A relação de pertinência, que na noção de administração se encerra, sobrepõe-se à propriedade e abstrai dela. "Quoad dominium", - digamo-lo de passágem, - além dos pertencentes ocasionalmente a particulares, os bens de uso público comum abrangem no Direito Romano os "communia omnium": “aer, aqua profluens, et mare" (18); os "quae populi Romani sunt" (19): "litora maris" (20); "viae publicae" (21) "flumina publica" (22); e os communia civitatum". "veluti... theatra, stadia et similia". $\left.{ }^{23}\right)$. Com respeito a todos, porém, o uso comum assenta sôbre o mesmo princípio: nenhum dos utentes pode excluir os demais $\left({ }^{24}\right)$.

(16) Nossa Preparação cit., p. 61.

Tit, de (18) rerum, no. Cf $^{2}$.

(18) Cf. Dig. lib. I. Tit. VIII, de divisione rerum, fr. 2 , \& 1 .

Dig., lib. XLITI, tit. VIII, ne quid in loco publico, fr.

(21) Dig., lib. XLIII. Tit XI, de via prublica, fr 2.

Dig., lib. XXXIX, tit. TI, de damno infecto. fr. 24.

(24) Dig., lib. XLIII, tit. VIII, ne quid in loco publico, fr. 2 , \$ 12 : "Damnum pati videtur, qui commodum amittit, quod ex publico consequebatur, qualequale sit"' Cf III, cap. VIII, n. $0^{\circ} 26$, p. 33: "Item observandum est: quod usus harum rerum com munium ita omnibus competit, ut si quis in aliquo maris, aut fluminis publici diverti ca ratione, guia jam si mutuo se impedirent, et non conservateur in usu pens humanum. immo wotius orirentur rixae et sequeretur contrarius effectus contra juris naturalis intentum" id., lib. III, cap. IV, 11. ${ }^{\circ}$ 17, p. 12; "Nota tamen: quod licet omnibus licitum sit transire per viam pubican cum sequent, unusque el alter invicem se impediunt, 
I. B. Victor Proudhon advertiu, pois, oportunamente: “... tout homme qui, se trouvant en position de jouir de ces choses conformément à leur destination, en serait empêché par um autre, óprouverait une injustice à raison de laquelle il aurait le droit de se pourvoir par-devant l'autorité compétente pour en obtenir réparation, puisqu'un droit établi pour tous peut être revendiqué par tous" $\left({ }^{25}\right)$.

7. Ora, diametralmente opôsto é o princípio sôbre o qual assenta o exercício da propriedade privada. A construção jurídica. da propriedade privada baseia-se esencialmente sôbre o direito de excluir.

O reconhecimento cada vez mais nítido do conteúdo social da. propriedade não mais permite, decerto, aplicar-the a conhecida palavra de Binding, que a definia como um buraco escuro ao centro de um círculo de normas $\left({ }^{28}\right)$. Da essência mesma da propriedade é, não obstante, êsse direito de excluir que, "adversus omnes", se traduz, com relação a êstes, por uma obrigação generalizada, consistente "na inação, isto é, na abstenção de qualquer ato que possa estorvar o direito" (27). E quando se diz que os direitos de crédito se originam e executam também "erga omnes", afirma-se, a respeito dêles, meramente uma virtude da propriedade (28), tomada aqui em acepção mais ampla, compreendendo "a universidade dos objetos exteriores, corpóreos e incorpóreos, que constituem a fortuna ou patrimônio de cada um" $\left({ }^{29}\right)$.

Um juízo apressado levaria, de tal sorte, fàcilmente à conclusão de que a propriedade privada e o domínio público são construções jurídicas que, antagônicas, nunca se teriam unido nem jamais. poderiam vir a unir-se. A realidade, entretanto, é bem diversa.

8. O homem tem um corpo, ocupa um lugar no espaço. As. cousas corpóreas acompanham-no nessa condição. Supostas, pois, uma coletividade de homens e uma cousa corpórea, de uso comum, acessível a todos, é visto que "o uso por qualquer dêles seria, num local e num momento dados, obstáculo material ao uso dos demais" $\left.{ }^{30}\right)$.

Materialmente, portanto, o utente de um bem do domínio público exclui, num lugar e num momento dados, todos os demars, na mesma medida em que êstes, jurìdicamente, não o podem excluir, a

(25) Traité du Domaine Public, t. I, Paris, 1843, n. 16 , p. 20.

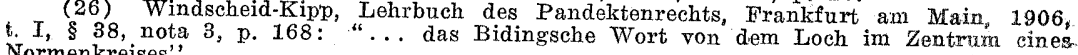

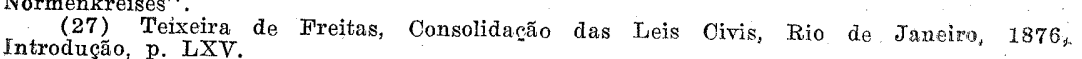

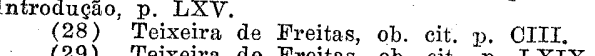

(29) Teixeira de Freitas, ob. cit., p. LXIX. êle, enquanto ao uso do bem. Essa verificação fizeram-na já Cím cero e Sêneca.

Cícero observou: "sed, quemadmodum, theatrum ut commune sit, recte tamen dici potest, ejus esse eum locum, quem quisque occuparit" $\left.{ }^{31}\right)$. E Sêneca: "equestra omnium equitum Romano-" rum sunt: in illis tamen locus meus fit proprius, quem occupavi" $\left({ }^{32}\right)$.

Não é diferente a linguagem dos juristas clássicos, acêrca das praias do mar, "quae populi Romani sunt" ( $\left.{ }^{33}\right)$. Ulpiano escreveu: "quod si (quis)... in titore aedificet, licet in suo non aedificet, jure tamen gentium suum facit" $\left.{ }^{34}\right)$. Mas êsse "suum" é limitado no tempo; dura, apenas, enquanto dura a ocupação privada privede: “... aedificio dilapso, quasi jure postlimini revertituio locus in prstinam causam; et si alius in eodem loco aedificaverit, ijus fiet" ( ${ }^{36}$ ).

Quanto às "res communes omnium", os mesmos são os rumos da jurisprudência clássica. Ulpiano, a estas equiparava-lhes já as praias do mar: "... mare commune omnium est, et litora, sicuti aer" $\left.{ }^{(36}\right)$. E essa foi, de resto, por intermédio de Marciano $(37)$, a lição recebida nas Institutas: "... naturali jure communia sunt omnium haec: aer, aqua profluens, et mare et per hoc litora" ${ }^{(38)}$.

Ainda que os textos o não dissessem, como dizem, fora de dút. vida é, porém, que o uso individual da cousa, de uso público cor mum, haveria de importar necessàriamente uma exclusão conatural de uso idêntico da mesma cousa, ao mesmo tempo, no mesmo lugar. As leis da natureza não subjazem às leis jurídicas.

9. Traduzir-se-á, acaso, nesse uso, comum - comum, jurídicamente; exclusivo, fisicamente, - uma forma anômala de propriedade, tal a propriedade coletiva ou, seja, a compropriedade, sem autonomia de quinhões individuais $\left({ }^{39}\right)$ ?

Parece-nos que não. $\mathrm{O}$ modêlo, que essa construção jurídicât reproduz, ainda é o da propriedade individual. $O$ uso individual da cousa, de uso público comum, retrata, ainda que imperfeitamente, a figura jurídica da ocupação, enquanto modo de adquirir.

(31) De Finibus, lib. III, cap. XX (Ed. Didot, Paris, 1875, t. III); cf. Alfred Pernice, Marcus Antistius (32) De Belle, 1873, p. 271 .

(33) Cf. Dig., lib. XLIII, tit, VIII, ne quid in loco publico, fr.

(34) Dig., lib. XXXIX, tit. I, de operis novi nuntiatione, fr. $1, \$ 18$

(35) Dig., lib. I, tit. VIIII, de divisione rerum, fr. 6 .

(37) Dig., lib. I, tit. VIII, de divisione rerum, fr. $2, \$ 1$.

(38) Inst., lib. II, tit. I, de divisione rerum, \& 1. 1 . I, Paris, 1925, N.o $3005, \mathrm{p}$. 985. "Exempli gratia", Waline, Les Mutations Domaniales, Paris, 1925, p. 196: "Nous
dirons donc, avec M. Planiol, que le Domaine Public est la propriété collective de lia Nation". 
Das cousas, de uso comum, do domínio público, Nerácio disse excelentemente: "nec dissimilis conditio eorum est, atque piscium et ferarum; quae simul atque adprehensae sunt, sine dubio ejus, in cujus potestatem pervenerunt, dominii fiunt" $\left({ }^{40}\right)$. Um traço, apenas falta à semelhança: a perpetuidade do domínio assim adquirido. Vinnio sinalou, a êsse propósito, com exatidão: "non simpliciter et absolute occupantis fiunt, sed dumtaxat interea dum occupat" (41)

Aos dois conceitos, o de propriedade privada e o de domínio público, o característico, neste último, do uso comum, indica-lhes, pois, uma formação correlata, em que um traço, apenas, opera como divisor fundamental. Esse traço é o tempo. $\mathrm{Na}$ propriedade privada, a virtualidade do uso individual entende-se perpétua; no domínio público, transitória.

10. A perpetuidade da propriedade romana explica-se, de modo imediato, por causas políticas. "Era a propriedade genuín do povo quírite, - a observação é de Pietro Bonfante, - um direito sôbre a cousa, ilimitado no espaço e no tempo, direito que sôbre o imóvel, tem todo o caráter, todo o espírito de uma verda deira soberania territorial, fechada em si mesma e independente $(42)$

Há nessa perpetuidade, entretanto, uma conveniência manifesta com a essência espiritual do homem: "expressão de nossa vonta de sôbre a natureza física, o domínio aspira a ter extensão igual à da nossa própria vontade" $\left.{ }^{43}\right)$. Na verdade, se o espírito é imortal, perpétuo deve ser, também, o domínio, por que êle afirma seu primado sôbre as cousas.

A perpetuidade é, ao demais, a vocação metafísica do homem. O "élan" ontológico, que se ergue da matéria, vitalizável, à vida espiritualizável, e desta, ao espírito, nalguma medida e pela graca, deificável ${ }^{44}$ ), traduz-se, face ao tempo, por um correspondente esfôrço de libertação; do tempo intrínseco, que é o da matéria, chumbado à condição desta, permanente mas corruptível, natéria, se um degráu, na escala da liberdade, para atingir o tempo discreto ou descontínuo, seqüência de operaçôes vegetativas e sensitivas, que é o da vida $\left({ }^{45}\right)$, e dêste, mais um degráu ainda, para alcancar eviterno, no qual o espírito, de alguma forma, participa da divina

(40) Dig., lib. XLI tit. I, de adquirendo rerum dominio, fr. 14. (41) Institutionum Imperialium Oommentarius, Logduni, 1755, lib, it tit I (42) Storia del Diritto Romano, t. I, Milano, 1923, p. 179. p. 76. Lacerda de Almeida, Direito das Cousas, t. I, Rio de Janeiro, 1908, § 9 ,

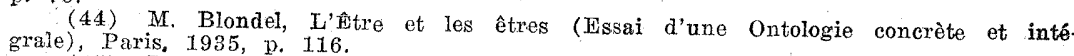
(45) Bergson, I, Evolution Oréatrice, Paris, 1929, p. 31: “... on pourrait dire reternidade ( $\left.{ }^{46}\right)$, que é, afinal, possuível pela contemplação eviterma, e verdadeira libertação de todo o tempo ( $\left.{ }^{47}\right)$. Nesse "élan" supremo, as cousas suspendem-se ao homem, alçam-se com êle ao eviterno, servindo-lhe como de lastro na ascensão e como se anteparo à irradiação cegante da luz divina (48).

O domínio, o vínculo jurídico, pelo qual essas mesmas cousas se prendem ao homem, não poderia, pois, deixar de sobrepor-se ao tempo, comensurando-se, antes, à eviternidade, a que o homem as arrasta em subida ciclicamente incessante pelos degráus do ser. A administração, ao contrário, como tipo distinto de relacionamento jurídico, vincula os bens do domínio público, a un fim essencialmente temporal, abstraindo, por completo, da pessoa, a cujo destino morall se encontrem êles ligados pelo laço da propriedade.

Pela administração pública, provê-se aos fins da Cidade terrena, - "ad tuendam civium securitatem et ad vitam civilem tam commodiorem quam jucundiorem efficientam, totiusque reipublicae saJutem et prosperitatem promovendam" $\left({ }^{49}\right)$.

Mas, de qualquer maneira, como o céu se pode refletir na poça dágua, e a eternidade no tempo, assim também a propriedade privada, em tôda a sua grandeza, "sub specie aeterni", reflete-se na construção jurídica, "sub specie temporis", do domínio público.

Não se trata de conceitos antagônicos; são como linhas paralelas e, como a estas, podemos nós uní-los, se nos alteamos sôbre o finito, e, do infinito, os consideramos.

\section{APRESENTAÇÃO E DISCUSSÃO EM PLENÁRIO}

\section{Relator: JOÃO LEIT ÃO DE ABREU}

O SR. PRESIDENTE - José Salgado Martins - Temos sôbre a mesa a tese "DIREITO ADMINISTRATIVO E DIREITO PRIVADO", de autoria do nobre professor dr. Ruy Cirne Lima.

Concedo a palavra ao dr. João Leitão de Abreu, relator da tese

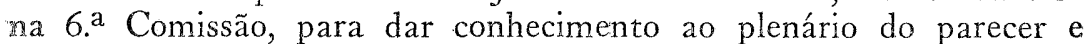
proceder a leitura da tese, conforme resolveu aquela Comissão.

O SR. JOÃO LEITÃO DE ABREU - Exmo. Sr. Presidente, senhores Congressistas, meus senhores.

(46) Santo Agostinho, De Civitate Dei, lib. III, cap. XIV (Opera Ommia, Ed. (47) VII, Parisiis, 1841): " $\ldots$ a temporalibus ad aeterna capienda".

(47) Nossa Preparação cit., p. 66 .
(48) M. Blondel ob. cit. p. 137 : Ils ont done pour ainsi dire un sort commun et ne peuvent se passer entièrement les uns des autres, soit pour realiser leur propre dégré d'existence en participant $\grave{a}$ des formes supérieures, soit. pour se servir de lest dano ur ascension et comme d'écran contre l'irradiation aveuglante d'une divine lumière". 26 - R. D. - $20^{\circ} \mathrm{Vol}$. 
Eis o parecer aprovado pela $6 .^{a}$ Comissão:

"Partindo da asserção de que a intransigência em manter rgorosamente a velha distinção romana entre Direito Público e Direito Privado vem gerando ,na literatura do Direito Administrativo, a multiplicação de "novidades", que só o esquecimento completo dos dogmas privatísticos autorizaria fôssem consideradas tais, conclui o ilustre professor Ruy Cirne Lima mostrar-se oportuno empreender o estudo dos institutos e figuras jurídicas do Direito Administrativo, em comparação com as espécies paralelas do Direito Privado, criando-se, destarte, um como Direito Comparado "ad intra", nesse setor importantíssimo da investigação jurídica. Como contribuição a êsse "desideratum", elaborou ensaios sôbre "Ato administrativo e ato jurídico privado" e "Domínio público e propriedade privada". Como a totalidade dos membros da Comissão não só tem conhecimento pessoal e direto dos têrmos da tese do professor Ruy Cirne Lima, como concorda, ainda, plenamente, com as conclusões a que, com. a habitual maestria, chegou o eminente jurisconsulto, deliberou a mesma Comissão encaminhar a aludida tese ao plenário do Congresso com a recomendação de que a aprove integralmente. Tratando-se por outro lado, de trabalho não muito extenso, resolveu, também, a Comissão dispensar o relatório acêrca da tese e designar um dos seus membros para, em plenário, proceder-lhe à leitura".

Cumprindo essa determinação, o relator passou a ler a tese do professor Cirne Lima, que mereceu integral aprovação do plenário.

\section{NATUREZA JURÍDICA DA CONCESSÃO DO SERVIÇO PÚBLICO}

Oswaldo Aranha Bandeira de Mello

Professor Catedrático da Faculdade Paulista de $\mathrm{Di}_{\text {- }}$ reito da Pontifícia Universidade Católica de São Paulo.

Capítulo I

\section{DO SERVICO PÚBLICO}

1 - A vida isolada do homem, é, em regra geral, impossível. Pela própria natureza, são os entes humanos impelidos a viver em sociedade. Além disso, percebendo as vantagens que resultam da cooperação dos seus semelhantes, não podem deixar de desejá-la. Temos, portanto, que a vida social é uma resultante dêsses dois ele-m mentos: necessidade e liberdade.

Daí, o dever de colaboração recíproca, concretizado no princípio de solidariedade, não só impôsto pela própria natureza, como, ainda, querido, por verificar-se que convém à vida em comum.

O meio exterior apropriado é fisicamente adequado ao desenvolvimento do nosso organismo, para êste percorrer o ciclo natural da sua evolução. Por sua vez, o meio social apropriado é psicològicamente adequado aos nossos sentimentos e aos nossos pensamentos, para se manifestarem e se aprimorarem.

Para que a vida em sociedade possa frutificar, exige a prática de certas atividades e, por outro lado, a abstenção de outras. Isto, é, tôdas aquelas atividades que contribuem para a vida social próspera devem ser praticadas, bem como devem ser evitadas tôdas as que lhe forem prejudiciais. Eis aí, a conclusão imposta: a união dos esforços individuais para a realização de fím comum, constituidor do bem da coletividade.

A expansão da personalidade humana exige, - e isso é de senso comum - a formação de várias sociedades, algumas naturais e outras convencionais, sendo, conseqüentemente, necessárias as primeiras e voluntárias as segundas. 